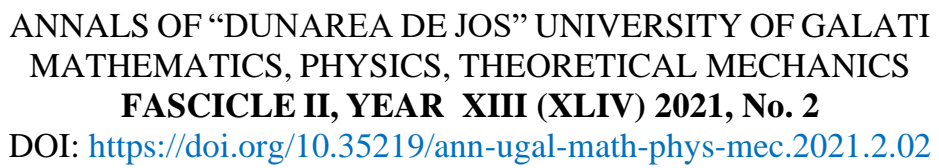

\title{
Contemporary technologies in research to control and reduce the health risk of radon exposure
}

\author{
Ababii Aurelia \\ National Agency for Public Health, 67A Gheorghe Asachi Street, Chisinau. Republic of Moldova \\ Corresponding author: aurelia.ababii@ansp.gov.md
}

\begin{abstract}
Ionizing radiation of terrestrial origin is a topic of global interest and the main objective is the study of the medical-biological effects on health. The academic community is in continuous research on the development of methods for detecting them. One of the most important elements participating in the creation of the natural background of ionizing radiation, with a major impact on health is radon. It cannot be perceived by the human senses as it is an odorless, colorless, and tasteless gas. Radon inhaled into the alveoli of the lungs disrupts the main cellular processes, the translation and transcription of DNA and RNA molecules, thus occurring a series of mutations in the genetic apparatus. Exposure to high levels of radon is the second leading cause of lung cancer after tobacco use.

Determining the concentration of radon in the air of residential homes, public buildings and workplaces is a priority action for the development and implementation of the action plan in the context of the objectives of EURATOM Directive 59/2013.
\end{abstract}

Keywords: radon, detectors, health risk

\section{INTRODUCTION}

Radon is a ubiquitous radioactive gas with a major impact on international public health systems and epidemiological studies show that its medical and biological effects can no longer be neglected and require systematic monitoring and policies aimed at controlling and remedying high-risk situations for the general condition of the population. The study of radon in terms of its involvement in the etiology of bronchopulmonary cancer is an important step in raising awareness about the risks of exposure to this gas. The share of bronchopulmonary cancers (out of the total number), caused by radon is $3-14 \%$, a percentage that is in a relationship of interdependence with the average concentration of radon in the country. According to UNSCEAR, radon is responsible for about $70 \%$ of the total effective dose of exposure of the population to natural ionizing radiation sources and $50 \%$ of the total exposure to ionizing radiation [1,2]. The effects of radon are largely attributed to the inhalation of both the gas and its disintegrants. The process of radon accumulation in the respiratory tract is dependent on its attachment to particles, the particle size determines the ability to migrate from the upper to lower airways to the lung alveoli, where it accumulates over a period equivalent to the time of disintegration in short-lived offspring [3].

In radon research, there are three essential elements that need to be elucidated to define the exposure doses of the population, namely the presence of radon in groundwater, soil, and indoor air [4]. 
Measuring the concentration of residential radon, mapping it, and calculating the doses of radon exposure of the population of the Republic of Moldova is a relevant factor for approving and implementing the national action plan to address the problem of increased incidence of bronchopulmonary cancer as a result of radon. Being present in outdoor air in relatively moderate amounts, radon can reach critical levels indoors, in homes or workplaces. The accumulation depends on a number of microclimate factors, construction features, and seasonal factors [5].

The individual risk levels associated with radon differ because analyzing this indicator shows a number of determining factors. Exposure to high concentrations of radon in association with tobacco use in both current and ex-smokers or people who have never used tobacco increases the risk of bronchopulmonary cancer per unit of radon exposure. The distribution of bronchopulmonary tumors associated with this gas needs to be analyzed in terms of extended models of energy of other essential elements with implications for general health $[4,6,7]$.

Therefore, the permanent monitoring of the concentration of residential radon is a priority in the strategy of population protection and risk communication. In order to achieve the objectives regarding the quantification of the risk associated with radon, an experimental, descriptive, and analytical study will be carried out to determine the concentration of radon on the territory of the Republic of Moldova in the context of EURATOM Directive 59/2013. The application of the most efficient techniques for measuring, monitoring, and processing qualitative data will allow the identification of high risk areas, defining the link between abiotic environmental factors and seasonal variations in concentration, and highlighting other factors influencing the detection of values above the maximum allowable limit. Currently, a number of factors are declared that can influence radon concentrations in homes, among them are: geotectonic of the land adjacent to the building, season, construction materials used, type of home, location of the detector (basement, ground floor, floor), ventilation, sealing technologies and the room heating system [8].

Previous national and international practice has shown that the most appropriate methods of monitoring radon concentration are long-term passive methods. They allow the recording of radon concentrations over a period of time, offering the possibility of calculating a dose that actually reflects the exposure dose. Long-term methods have the main advantage that the recorded dose has not been influenced by microclimate factors, room ventilation, or other processes that may be related to residential radon values. Fluctuations in radon concentration in the room can be determined depending on the days of the week. Thus, a study conducted between October 2019 - May 2020, throughout Romania, provides interesting results in terms of radon values, respectively the concentration over 300 $\mathrm{Bq} / \mathrm{m}^{3}$ it is attested on Monday morning, gradually decreasing and reaching the minimum level of 20 $\mathrm{Bq} / \mathrm{m}^{3}$ on Thursday and Friday, then the curve is again constantly increasing on holidays $[9,10]$. From the above, the use of contemporary integrative radon concentration measurement technologies is indispensable and scientifically argued.

\section{EXPERIMENTAL}

To determine the exposure doses of the population to residential radon a number of methods are used, classified according to the types of measurements performed, thus defining instantaneous methods and integrative methods. The integrated method allows continuous and passive sampling of representative air samples, by means of a trace detector type CR-39, Radtrack2 (Fig.1), designed to measure the long-term radon concentration for 90 days. Radtrack 2 is a sufficiently accurate detector that allows the recording of fluctuations in radon levels in the room for a period of up to one year, thus providing a real average concentration, and due to the high precision, the research results will provide a complex and essential approach. 


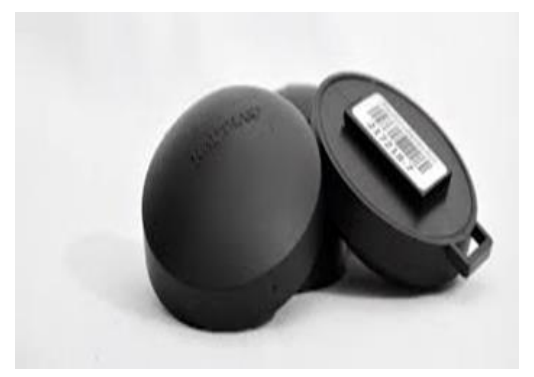

Fig.1. Radtrak ${ }^{2}$ Alpha Track. Alpha trace detector for long-term radon measurements.

In terms of measurement systems we distinguish between active (mechanically operated) and passive methods, according to the detection principle: alpha and gamma particles. The methods used can detect only ${ }^{222} \mathrm{Rn}$ or ${ }^{220} \mathrm{Rn}$, and the measurement procedure can be performed in equilibrium or imbalance descendants [11].

At present, due to technological progress, research on radon concentration can take an advanced form by using intelligent radon detectors, such as Airthings Wave, which allows the recording of residential radon concentration from hour to hour while transmitting warning signals exceeding the reference level of $300 \mathrm{~Bq} / \mathrm{m}^{3}$.

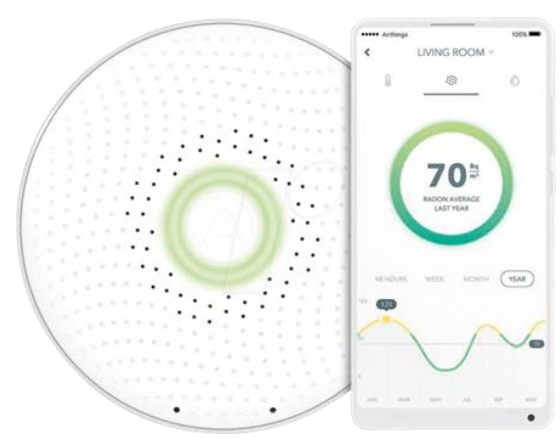

Fig. 2. Airthings Wave - Radon Detector Smart

Professional monitoring of radon in scientific research in conditions of gas fluctuations due to environmental factors can be achieved through a portable radon meter, AlphaGUARD (Fig.3), which shows high sensitivity, stable calibration and can simultaneously record the ambient temperature, humidity relative, atmospheric pressure with integrated sensors, which is extremely important in the analysis of the interdependence link between environmental abiotic factors and radon concentration.

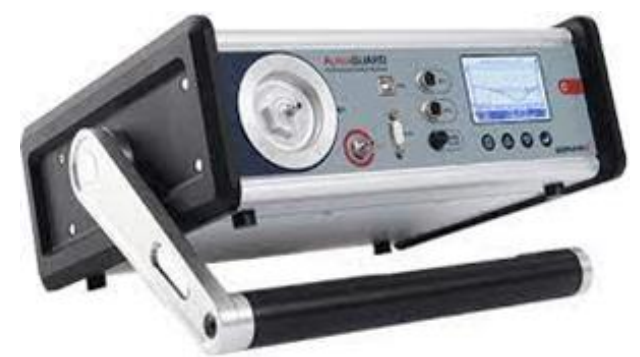

Fig.3. AlphaGUARD portable radon meter 
The most sensitive radon measuring instrument both in the field and in the laboratory is considered ATMOS, with high sensitivity and fast response time this device allows its use for the property inspection and subsequent measurements, but it is also a common reference tool for calibration chambers.

Another high-precision tool for monitoring radon in the soil is MARKUS 10, which records alpha radiation from radon progeny. Regardless of the type of measurement system, a mandatory condition in the validation of results is the proper calibration of the instruments by national or international laboratories. Within the laboratory infrastructure, it is possible to calibrate detectors using standard calibration. Verification of the reliability and quality of the methods used ensures consistent operating standards.

\section{RESULTS AND DISCUSSION}

The use of the best integrative technologies for continuous monitoring, control, and remediation of residential radon will substantially contribute to the development of a public health strategy and the adoption of a national action plan. The results of the research conducted during the years 2020-2023 will provide current data on exposure doses through an established methodology for measuring the concentration of residential radon. The obtained data will be processed within the programs SPSS, Excel, and Statistics 7. For each region and country, the indicators of the central trend (average, median, and module) will be calculated, the degree of scattering of values by calculating the standard deviation, accurate indicator of spreading the series values with the possibility of obtaining a clear picture of fluctuations in radon concentration from one region to another and establishing the causal link with environmental factors, soil type, coefficient of variation and dispersion. The analysis of the results must also include the sampling scheme to obtain representative estimates of the radon concentration distribution parameters indoors. Therefore in this research for a representative sample, the dwellings will be chosen at random and will include both private houses on the ground as well as blocks of flats $[12,13]$. In particular, the probability of each dwelling being included in the sample is equal. The results obtained from the measurements will subsequently contribute to the creation of the radon map on the territory of the country, a measure recommended under the EURATOM/53/2013 Directive. For the realization of the radon map in the dwellings of the Republic of Moldova will be used the scientific research methodology of the Joint Research Center within the EC. The grid established in the Lambert-GISCO system will be used, according to which the territory of the Republic of Moldova is represented by 336 cells with sides of $10 \times 10 \mathrm{~km}^{2}$.

Based on the multiple quantifications of the radon concentrations in the indoor air of the dwellings on the territory of the Republic of Moldova, the risk of exposure of the population of the Republic of Moldova to radon will be calculated: the exposure doses of the population to radon will be calculated; localities with an increased risk of radon exposure will be elucidated. Updating national population radiation protection standards is a necessity and a priority according to the EC (EURATOM/53/2013) and WHO recommendations and the reference levels of radon in housing will be established.

\section{CONCLUSIONS}

1. Establishing radon concentrations in the air in dwellings located in rural and urban areas of geographical areas of the Republic of Moldova by long-lasting and active-passive methods using contemporary technologies for measuring and processing results will allow the development of intelligent quality improvement solutions indoor air.

2. Based on the results obtained from the research, it will be possible to update the methodology for measuring radon concentrations in the air in homes, establishing regulations and indications for monitoring radon levels. 
3. In the process of assessing the annual effective doses and quantifying the risk of exposure of the population to radon, an important step is the use of efficient methods and validated by international bodies in the field, as well as the most innovative devices accredited by the competent bodies.

\section{References}

1. Nancy V.H., Gary G. S., Radon and lung cancer: What does the public really know? Journal of Environmental Radioactivity, 192 (2018) 26-31.

2. UNSCEAR I. Sources and effects of ionizing radiation. United Nations Scientific Committee on the Effects of Atomic Radiation, 2008. United Nations, New York, 2010.

3. Man-Made Mineral Fibres and Radon. IARC Monographs on the Evaluation of the Carcinogenic Risks to Humans 43, 1988, 239-241.

4. Chahine T., Schultz B., Modeling Joint Exposures and Health Outcomes for Cumulative Risk Assessment: The Case of Radon and Smoking, Int. J. Environ. Res. Public Health, 2011, 8(9), 3688-3711; Available from: https://doi.org/10.3390/ijerph8093688 [Accessed 24.11.2021].

5. Corețchi L., Bahnarel I., Apostol I., Vîrlan S. Controlul, reglementarea, și remedierea expunerii la radon a populației Republicii Moldova. Chișinău, 2020, 7-94.

6. Hunter N., Muirhead C. Calculation of lifetime lung cancer risks associated with radon exposure, based on various models and exposure scenarios, Journal of Radiological Protection, 35, no. 3, Available from: https://iopscience.iop.org/article/10.1088/09524746/35/3/539 [Accessed 20.11.2021].

7. Vîrlan S., Corețchi L., Bahnarel I., Metodologia monitorizării surselor naturale de radon $\left({ }^{222} R n\right)$ și evaluarea riscului radiologic pentru populația expusă. Indicaţii metodice. Chişinău, 2014.

8. Măsurători de radon. Dositracker. https://dositracker.ro/wp-content/uploads/2020/11/02DOSITRACKER-m\%C4\%83surarea-concentra\%C8\%9Biei-de-radon.pdf

[Accessed 20.11.2021].

9. Papp B., Radonul și fluxul de radon din sol. Aplicații în mediu, geologie și geofizică, ClujNapoca, 2011, 3-34.

10. Avadanei C., Noua evaluare a riscului radonului. Examinări Nedistructive, 2 (6) (2016) 9-14.

11. National And Regional Surveys Of Radon Concentration In Dwellings. Review of Methodology and Measurement Techniques, IAEA, Vienna, 2013.

12. Report on indoor and geogenic radon surveys in Europe, including their strategies, the methodologies employed, inconsistencies in the results, and potential methodologies to harmonize data and reduce inconsistencies European Commission, 16-ENV 10 MetroRADON, Joint Research Centre, Ispra, Italy (JRC), 2019.

13. Beck F., Richard J. B., Deutsch A., Benmarhnia T., Pirard P., Roudier C., Peretti-watel P., et al., Connaissance et perception du risque dû au radon en France. Cancer/Radiothérapie, 8(17) (2013) 744-749. 